\title{
Assessment of cardiac functions in thalassemia patients with $\mathrm{m}$-mode echocardiography
}

\section{Talasemili hastaların kardiyak fonksiyonunun m-mod ekokardiyografi ile değerlendirilmesi}

\author{
Sultan Aydın Köker ${ }^{1}$, Gönül Oktay², Derya Duman ${ }^{3}$, Hasan Demetgül ${ }^{3}$, Alper Köker ${ }^{2}$, Yasemin \\ Çoban², Go̊kçen Öz Tunçer ${ }^{2}$, Yillmaz Akbaș², Tugçe Tural Kara²
}

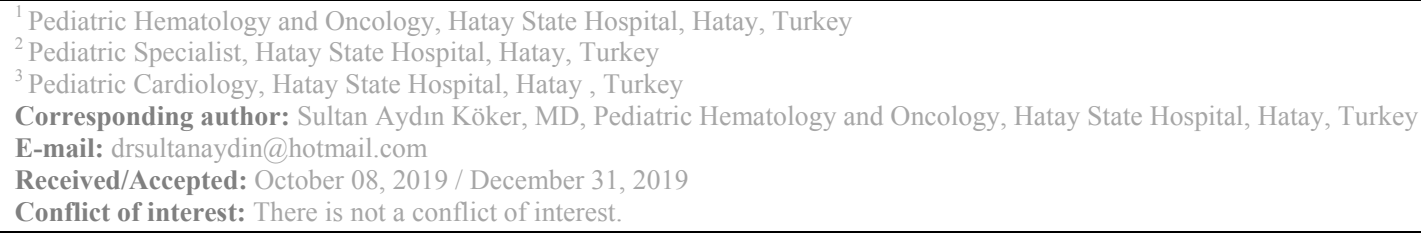

\section{SUMMARY}

Objective: Although there is increased survival and quality of life for thalassemia patients, which results from a genetic defect in globin synthesis, heart diseases are still important causes of morbidity and mortality related to the iron burden. Therefore, we aimed to evaluate the cardiac functions of thalassemia patients followed up in Hatay State Hospital using echocardiography.

Method: A total of 101 patients with 7 thalassemia intermedia and 94 thalassemia major who were followed at Hatay state hospital were examined retrospectively. Of patients, 47 were male and 54 were female. Their ages ranged between 1-17 years (mean 8.6 \pm 4.6 years). M-mode echocardiography was used to measure LVEDd (left ventricular enddiastolic diameter) and EF (ejection fraction). The demographic and laboratory values of the patients were obtained from their files.

Results: The mean of LVEDd (mm) and EF (\%) were evaluated as $34.8 \pm 6.1$, and $66.36 \pm 1.4$ with M-mode echocardiography, respectively. When the correlation between age, ferritin and LVEDd and EF were evaluated; it was determined that there was a high positive correlation $(\mathrm{r}=0.649)$ between age and LVEDd $(\mathrm{p}<0.01)$. A negative correlation was detected between ferritin and EF $(r=-0.271)(p<0.01)$. EF was found to be significantly lower in the group with ferritin $<2000$. LVEDd was found to be increased in the group with ferritin $>2000$, although it was not statistically significant.

Conclusions: In our study, it was shown that EF was decreased with increasing ferritin and LVEDS was increased with increasing age of patients with thalassemia. The ideal ferritin level which was ensured after suitable chelation therapy should be an important goal to reduce cardiac involvement.

Keywords: Thalassemia, ferritin, ejection fraction, echocardiography
Sultan Aydın Köker

ORCID IDs of the authors: S.A.K. 0000-0002-8801-7776

\section{ÖZET}

Amaç: Globulin sentezinde genetik bir defekt sonucu gelişen talasemide görülen komplikasyonlar hastalığın kendisine ve uygulanan tedavilere bağlı gelișmektedir. Hastaların yaşam süresi ve kalitesi giderek artmakla birlikte halen demir yüküne bağlı olarak kalp hastalıkları (kalp yetmezliği ve aritmiler) önemli morbidite ve mortalite nedeni olmaktadır. Bu 
nedenle Hatay devlet hastanesi Talasemi ünitesinde takip edilen talasemi hastalarının kardiyak fonksiyonlarmnı ekokardiyografi ile değerlendirilmeyi amaçladık.

Yöntem: Hatay devlet hastanesi Talasemi ünitesinde izlenmekte olan transfüzyon bağımlı 7 talasemi intermedialı ve 94 talasemi majorlu toplam 101 hasta retrospektif olarak incelenmiștir. Toplam talasemi hastalarının 47'si erkek, 54'ü kız olup, yaşları 1-17 yıl (ortalama 8.6 4 4.6 yıl) arasında değişmektedir. Bu hastaların yapılmış ekokardiyografilerinde Mmod ekokardiyografik inceleme ile SVDSÇ (sol ventrikul diyastol sonu çapı) ölçülmüş, EF (ejeksiyon fraksiyonu) alet tarafından hesaplanarak kaydedilmiştir. Hastaların demografik ve labotuvar değerleri dosyalarından elde edildi.

Bulgular: Toplam 101 hastada yapılan ekokardiyografi değerlendirilmesinde, SVDSÇ (mm) ortalama 34.8 \pm 6.1 , ve EF (\%) ortalama 66.36 \pm 1.4 saptandı. Yaş, ferritin ile SVDSÇ ve EF arasında korelasyon değerlendirildiğinde; yaş ile SVDSÇ arasında pozitif yönlü yüksek korelasyon olduğu $(r=0,649)$ belirlenmiştir $(\mathrm{p}<0,01)$. Ferritin ile EF arasında negatif yönlü orta seviyede $(r=-0,271)$ ilişkinin olduğu saptanmıştır $(\mathrm{p}<0,01)$. Özellikle ferritin 2000 üstünde olan grupta, EF istatistiksel olarak anlamlı olarak daha düşük saptandı. SVDSÇ istatistiksel olarak anlamlı olmasa da ferritin 2000 üzerindeki grupta artmış olarak saptandı.

Sonuç: Çalışmamızda talasemilerde ferritin artıkça özellikle EF azaldığı, yaş arttıkça da SVDSÇ artış ile kardiyak disfonksiyon geliştiği gösterildi. Zamanında ve uygun şelasyon tedavisi ile ideal ferritin seviyesi sağlanarak kardiyak etkilenmeyi azalmak önemli bir hedef olmalıdır.

Anahtar sözcükler: Talasemi, ferritin, ekokardiyografi, ejeksiyon fraksiyonu

\section{INTRODUCTION}

Thalassemia is a disease characterized by hypochromic microcytic anemia development as a result of low or no synthesis of the hemoglobin ( $\mathrm{Hb})$ chain defined as $\alpha, \beta, \gamma$ and $\delta$. Thalassemia carriers are divided into two subgroups of thalassemia intermedia and thalassemia major. Thalassemia major, especially, may have a severe clinical tableau dependent on transfusions ${ }^{1}$. In thalassemia major patients, transfusion-linked iron accumulation is responsible for morbidity and mortality. Iron accumulation, especially, may cause cardiac complications like pericarditis, myocarditis, or congestive heart failure and mortality at advanced age. Ferritin is the most common biochemical parameter used to assess iron accumulation. Studies have found that patients with continuously high ferritin levels $(>2500 \mathrm{ng} / \mathrm{mL})$ have high rates of cardiac effects. Especially in patients with low ferritin $(<1000$ $\mathrm{ng} / \mathrm{mL}$ ) cardiac problems were identified to be low ${ }^{2}$.

The results of studies from recent years have reported left ventricular diastolic function disorder is responsible for many heart diseases. In fact, it was identified that diastolic function was affected before the development of systolic function disorder ${ }^{3,4}$. Echocardiography is a method used to assess both systolic and diastolic function ${ }^{5}$.

As a result, in this research we aimed to investigate transfusion-dependent patients monitored by the thalassemia unit with both thalassemia major and intermedia with echocardiographic investigation to assess cardiac findings and research correlations with serum ferritin and demographic information.

\section{MATERIAL AND METHODS}

\section{Study Group}

The study included a total of 101 patients, 7 with thalassemia intermedia and 94 with thalassemia major, monitored by Hatay State Hospital thalassemia unit aged less than 18 years, receiving regular blood transfusions and without known congenital or acquired heart disease. Of patients, 47 were male and 54 were female with ages ranging from 1 to 17 years (mean 8.6 \pm 4.6 years).

\section{Hematologic Assessment}

Patient demographic characteristics were obtained from the monitoring cards in the thalassemia unit. Patients had transfusion with an erythrocyte suspension every 3-6 weeks to ensure pretransfusion hemoglobin levels were 9-9.5 g/dL. All patients used $20-40 \mathrm{mg} / \mathrm{kg} /$ day deferasirox and folbiol by the oral route.

\section{Cardiac Assessment}

\section{Echocardiographic Study}

Two-dimensional M-mode echocardiography studies were performed using a Toshiba SSH$160 \mathrm{~A}$ echocardiograph and $3.75,5$ and $1.5 \mathrm{mHz}$ transducer. During echocardiographic investigation simultaneous ECG and phonocardiogram records were taken, with all measurements taken separately during at least 3 cardiac cycles and mean values calculated.

M-mode echocardiographic investigation recorded left ventricular end diastolic diameter (LVEDd) and ejection fraction (EF) calculated by the device.

For statistical analysis of results, the $t$ test and Pearson's correlation test were used. 


\section{RESULTS}

M-mode echocardiographic evaluations of a total of 101 patients identified LVEDd (mm) as mean $34.8 \pm 6.1$, and mean EF (\%) as $66.36 \pm 1.4$.

The systolic functions examined with m-mode echocardiography for 101 thalassemia patients and their ferritin levels were compared as above and below 2000. Left ventricular systolic function measurements of EF were identified to be statistically significantly low $(\mathrm{p}=0.021)($ Table 1$)$. There was no significant difference identified for LVEDd.
Table 2 shows the age and left ventricular systolic function measurements for thalassemia patients. Thalassemia patients aged over 12 years were identified to have a statistical increase in LVEDd $(\mathrm{p}=0.001)$.

Table 3 shows the left ventricular systolic function measurements for thalassemia patients with sex. LVEDd (mm) was identified to show a statistically significant increase in male thalassemia patients $(\mathrm{p}=0.001)$.

Table 1: The relationship with ferritin between EF and LVEDd

\begin{tabular}{|l|l|l|c|}
\hline & Ferritin $<2000$ & Ferritin $\geq 2000$ & P \\
\hline EF (\%) & $66.72 \pm 0.245$ & $66.04 \pm 0.158$ & $\mathbf{0 , 0 2 1}$ \\
\hline LVEDd $(\mathrm{mm})$ & $34.77 \pm 1.042$ & $34.83 \pm 0.724$ & 0,962 \\
\hline
\end{tabular}

Table 2. Mean and standard deviations of EF and LVEDd according to age

\begin{tabular}{|l|l|l|c|}
\hline & Yaş $<12(\mathrm{n}=77)$ & Yaş>12 $(\mathrm{n}=23)$ & $\mathrm{P}$ \\
\hline EF $(\%)$ & $66.36 \pm 0.170$ & $66.35 \pm 0.271$ & 0,964 \\
\hline LVEDd $(\mathrm{mm})$ & $33.39 \pm 0.623$ & $39.61 \pm 1.248$ & $\mathbf{0 , 0 0 1}$ \\
\hline
\end{tabular}

Table 3. Mean and standard deviations of EF and LVEDd according to gender

\begin{tabular}{|l|l|l|l|}
\hline & Female $(\mathrm{n}=53)$ & Male $(\mathrm{n}=47)$ & $\mathrm{P}$ \\
\hline EF (\%) & $66.30 \pm 0.156$ & $66.43 \pm 0.254$ & 0,673 \\
\hline LVEDd $(\mathrm{mm})$ & $32.98 \pm 0.789$ & $36.89 \pm 0.872$ & $\mathbf{0 , 0 0 1}$ \\
\hline
\end{tabular}

A positive high-level correlation was determined between age and LVEDd $(\mathrm{mm})(\mathrm{r}=0.649, \mathrm{p}<0.01)$. There was a negative and moderate-level correlation between ferritin and EF $(r=-0.271$, $\mathrm{p}<0.01)$. As age increased, LVEDd increased, while as ferritin level increased EF level was identified to fall.

\section{DISCUSSION}

The most common cause of death in transfusiondependent thalassemia patients is heart failure. Both increased gastrointestinal iron absorption and severe chronic anemia and resulting increase iron burden linked to blood transfusions cause myocardial iron accumulation leading to cardiac involvement ${ }^{6}$. Thalassemia patients survive a mean of 1 year from the occurrence of clinical symptoms of cardiac involvement. As a result, identification of cardiac involvement in the early period will be important to reduce mortality rates.

A study by Nazan et al. identified mean LVEDd as $38.4 \pm 4.7$ and $\mathrm{EF}$ as 71.9 \pm 4.2 , while in thalassemia major patients mean LVEDd was 43.4 \pm 7.3 and EF was 67.7 $\pm 5.2^{7}$. Another study of children with ventricular septal defect found LVEDd $(\mathrm{cm})$ as $3.42 \pm 0.66$ and EF as $72.6 \pm 6$, while the control group in this study had LVEDd (cm) $3.35 \pm 0.58$ and EF $73 \pm 5^{8}$. In our study, the $\mathrm{EF}$ values in thalassemia major patients were identified to be lower compared to the patient and control group in this study. However, none of our patients were identified to have EF value below $50 \%$. In conclusion, though our patients had not developed left ventricular dysfunction, they were 
determined to be at risk of developing heart failure due to low EF values. As a result, the need to take precautions to reduce iron accumulation was demonstrated.

Ferritin is known as an important biochemical parameter showing iron accumulation in the body of thalassemia patients. Especially those with ferritin $>1000 \mathrm{ng} / \mathrm{mL}$ have increased complication risk so it is recommended that chelation treatment begin with appropriate dose and appropriate administration form ${ }^{9}$. A study by Behzad et al. did not identify a difference in LVEDd while EF was low in thalassemia major patients with high ferritin ${ }^{10}$. Another study assessed cardiac functions of thalassemia major patients according to ferritin values (ferritin above and below 2500) and did not observe significant differences in both systolic and diastolic functions ${ }^{11}$. In our study, EF was identified to be lower in those with ferritin $>2000 \mathrm{ng} / \mathrm{mL}$. As age increased, an LVEDd increase was identified, while male sex was determined to show increased LVEDd.

In conclusion, it is important that necessary precautions are taken to determine the onset of disrupted cardiac functions before cardiac failure develops in thalassemia patients. As a result, all thalassemia patients should have echocardiography performed annually and if there are disruptions in measurements like EF or LVEDd, more frequent echocardiography checkups should be planned. Based on ferritin monitoring and changes in echocardiographic findings, early appropriate dose chelation should begin which will be an appropriate method to prevent development of cardiac failure.

\section{REFERENCES}

1. Quirolo K, Vichinsky E. Hemoglobinopathies. In: Kliegman RM. Behrman RE, Jenson HB, eds. Nelson Textbook of Pediatrics. 17th ed. WB Saunders Co.Philadelphia;2003: Chap.454.

2. Beutler E, Ferlitti V, Ho NJ, et al. Relationship of body iron stores to levels of serum ferritin, serum iron, unsaturated iron binding capacity and transferrin saturation in patients withiron storage disease. Acta Haematol 2002;107:145-9.
3. Spirlto P, Maron BJ: Doppler echocardiography for assessing left ventricular diastolic function. Ann Int Med.1988;109:122.

4. Vogel M, Anderson LJ, Holden S, et al. Tissue Doppler echocardiography in patients with thalassaemia detects early myocardial dysfunction related to myocardial iron overload. Eur Heart J. 2003;24:113-119.

5. Spirito P, Lupl G, Melevendi C, Vecchio $\mathrm{C}$ : Restrictive diastolic abnormalities identified by Doppler echocarQiography in patients with thalassaemia major. Circulation. 1990;82:88.

6. Lewls BS, Lewls N, Dagarı I, Rachmllewitz EA,Gotsman MS, Sapoznikov D: Studies of left ventricular function in anemia due to B-thalassaemia. Isr J Med Sci 18:928, 1982

7. Nazan ÖZBARLAS, Arınan BİLGIÇ, Fatma GÜMRÜK, Çiğdem ALTAY. Talasemili Hastalarda Sol Ventrikül Diyastolik Fonksiyonunun Doppler Ekokardiyografi ile Değerlendirilmesi. Türk Kardiyol Dern Arş 1993;21:85-89.

8. Mustafa KIR, Nurettin ÜNAL, Gül Sağın SAYLAM, Ulaş KARADAŞ, Murat ŞAHIN. Ventriküler septal defektli çocuklarda sol ventrikül fonksiyonlarının miyokardiyal perfromans indksi (Tei indeksi) kullanılarak değerlendirilmesi. Dokuz Eylül tıpl fakültesi dergisi. 2008;S:113-119.

9. Italian Society of Hematology practice guidelines fort he management of iron overload in thalassemia majör and related disorders. Haematologica 2008;93:741752.

10. Behzad A., Zahra B., Mahmoud M., Mahsa M. Evaluating the correlation between serum NT-proBNP level and diastolic dysfunction severity in betathalassemia majör patients. J Tehran Heart Cent. 2016;11:68-72.

11. Helen B., Kazım Ö., Erkan E.,Osen A. Assessment of left ventricular volüme and function in patients with beta thalassemia major. İKSST dergi. 2018;10:59-64. 